\title{
BRYOZOANS OF BANYOLES LAKE (NE SPAIN)
}

\section{Rieradevall ${ }^{1} \&$ J.M. Busquets ${ }^{2}$}

1. Departament d'Ecologia. Facultat de Biologia. Universitat de Barcelona. Avda. Diagonal 645, 08028 Barcelona. Spain.

2. Ambit de Recerques del Berguedà. C/. Huelva 106, 08020 Barcelona. Spain.

Keywords: Ectoprocta bryozoans, Phylactolaemata, statoblasts, Banyoles lake, Spain.

\begin{abstract}
Data for bryozoan species from Banyoles lake (NE Spain) are presented. Three species have been recorded: Fredericella sultana, Lophopus crystallinus and Plurnatella repens, the first two for the first time in the Iberian peninsula. An examination of the $\boldsymbol{F}$. sultana colony and the statoblast observations of L. crystallinus and $\boldsymbol{P}$. repens with the scanning electron microscope made possible the identification. Details of the floatoblast structure are given.
\end{abstract}

\section{INTRODUCTION}

Freshwater bryozoans had scarcely been studied in the Iberian peninsula. The published data refers only to Plumatella repens and Cristatella mucedo in the Pyrenees (MARGALEF, 1948, 1952) and the presence of Plumatella species (probably $\boldsymbol{P}$. repens or $\boldsymbol{P}$. fungosa) in Graugés and Serret ponds (Berguedà, Catalonia) detected by Busouets (1988).

On the other hand, Banyoles lake is the best known lake in Spain. Until the present, physicochemical cycles, fito and zooplancton, bacterial populations and other aspects have been studied (e.g.: Planas, 1973; Miracle, 1976; Guerrero et al. 1978). Recently, one of the authors of this paper started working on benthic communities from sublittoral and deep zones (RIERAdevall \& PRAT, in press); much is unknown about the littoral fauna. A first attempt and a general description of the littoral areas of the lake was made by MARGALEF (1946). Furthermore, severa1 studies on some zoological groups are relevant, mainly on snails (HaAs, 1916; Casadevall et al., 1985; Altaba,

Limnetica, 6: 137-146 (1990)

(C) Asociación Española de Limnología, Madrid, Spain
1985) and sponges (TrAveset, 1985), as well as other observations.

As in the deep and sublittoral benthic samples of the Banyoles lake, bryozoan statoblasts often appear, and due to the general interest of this lacustrine area and to the lack of data on bryozoans in Spain, we thought it interesting to make known the preliminary results obtained with the observation and identification of these material.

\section{MATERIAL AND METHODS}

\section{Study area}

Geographically, Banyoles lake is situated at $42^{\circ} 7^{\prime} \mathrm{N}, 2^{\circ} 45^{\prime} \mathrm{E}$ and at $175 \mathrm{~m}$ above sea level. Maximum length is $2130 \mathrm{~m}$ and its surface area is 118 $\mathrm{hm}^{2}$; mean depth is $15 \mathrm{~m}$ and maximum depth reaches $35-40 \mathrm{~m}$ or more (up to $130 \mathrm{~m}$ in one of the areas with suspended sediment and subterranean water source). The lake is the biggest water mass of a karstic system, which includes severa1 accompanying ponds, where the main entrance of water is by means of subterranean inflow. As a re- 
sult of deep water inflow, permanent suspended sediment is maintained in some deep parts of the lake and ponds. Water is rich in calcium and sulphate. The littoral zone $(0-3 \mathrm{~m})$ represents a thin strip, since the lake rapidly reaches $2-3 \mathrm{~m}$ deep. In outline, in the west and north areas of the lake macrophitic vegetation (Phragmites, Schoenoplectus, etc.) and several Myriophyllum meadows are abundant, while in the east and south areas vegetation is scarce and travertinic rocks are more important. Typical substrates in the littoral are slopes formed by the roots and detritus, and sediment with a high percentage of coarse particles and sizeable fragments of travertinic rocks.

Secchi disk depth ranged between 0,9 and 6,8 $\mathrm{m}$, in the $1986-87$ period. Minimum winter temperature was $4 " \mathrm{C}$, and in summer superficial water reached $25^{\circ} \mathrm{C}$ degrees. Conductivity and $\mathrm{pH}$ of superficial water are around $1300 \mu \mathrm{S} . \mathrm{cm}^{-2}$ and $7-8,15$ respectively. This is an oligotrophic lake with low nutrient content, with a cosmopolitan fito and zooplankton composition (PlanAs, 1973; MirACle, 1976). However this data does not agree with the benthic profundal fauna, which reflects mesotrophic conditions, due mainly to the lack of oxygen near the sediment during the stratification period (RIERADEVALL \& PRAT, in press).

\section{Methods}

In the present study we have used two types of material. Firstly, we collected live colonies of one of the identified species in several sporadic and random collections on the lake's shore. Colonies of Fredericella were transported alive to the laboratory and the colonies were studied and photographied. Secondly, we collected statoblasts from the sediment of the sublittoral and deep parts of the lake as a part of an extensive study on the benthic fauna of these areas. The sediment was sampled with an Ekmann dredge, filtered «in situ», through a $150 \mathrm{ym}$ net and fixed in $4 \%$ formalin. Then we sorted the sample under a stereomicroscope and preserved the material in $70 \%$ alcohol. Statoblasts were measured with an optical microscope using an excavate slide. Dehydrated material in absolute alcohol was observed with the scanning electron microscope (Cambridge S120 and Hitachi S2300); part of this material was air dried and part was prepared by the critical point method, and both were recovered with gold by sputtering.

\section{RESULTS}

Three species of freshwater bryozoans (Ectoprocta Phylactolaemata) occur in Banyoles lake: Fredericella sultana, Lophopus crystallinus and Plumatella repens. This is the first record in the Iberian peninsula for the former two although there is an unpublished observation of F. sultana in Banyoles lake (Olivella, unpubl. paper. 1974).

Class Phylactolaemata Allman, 1856

Family Fredericellidae Hyatt, 1868

Fredericella sultana (Blumenbach, 1779)

$F$. sultana is a cosmopolitan species, distributed from the Arctic to the Subantarctic regions, commonly found in many localities in Europe, North and South America, Australia and New Zealand (LACOURT, 1968; Bushnell, 1973). This species is euriterm, which could explain its wide distribution (it has been recorded at $3480 \mathrm{~m}$ ), although the species grows better at $20^{\circ} \mathrm{C}$ or less; it thus has the advantage of being able to grow in winter, while other ectoproct species cannot. F. sultana is a typical freshwater species, but can also live in brackish waters (LACOURT, 1968). It is frequently found in rivers, oligotrophic and eutrophic lakes and reservoirs, where it normally inhabits the shallow waters, although this species has been recorded at $214 \mathrm{~m}$ deep (GeImer \& MASSARD, 1986). Dense growths of the species are found on logs and plants, on stones and many different kinds of materials like plastics, bricks, roof tiles, wood fragments, trichoptera cases, etc. (BUSHNELL, 1974; Geimer \& MAssard, 1986). F. sultana is frequently associated with other ectoproct species, sponges and hidrozoans.

In Banyoles lake, Fredericella sultana grows on the lower lateral parts of stones and travertinic rock fragments, on submerged parts and roots of riverine plants and on stems of Myriophyllum verticillatum. We collected this species in the shallow areas of the littoral, but it is possible that colonies can grow in deeper parts. We could not find, in agreement with Olivella's observations, any colonies of other bryozoans, but more extensive and 
intensive survey is needed. OLivella (1974) points out the presence of $F$. sultana associated with the sponge Ephydatia fluviatilis.

Fredericella sultana colonies in the Banyoles lake are characterized by linear branching, similar to deer horns, with a cross section of $203 \mathrm{ym}$ to $339 \mathrm{ym}$, maximum values in the intersection of branches. The colony is attached to the substrate, with branches or individual zooids erect. The free branches have a circular or lightly triangular section; incrustant parts of the colonies have a clear triangular section and are dorsally keeled. Colonies are often light brown-yellowish in colour. The chitinous cuticle, or ectocist, is fully covered by fine mineral particles, diatoms frustuls and different epibionts like Vorticella, the ciliate Stentor, diatoms like Gomphonema and Cymbella, fila- mentous bacteria (Leptothrix), nematoda, small oligochaeta and hidracarina. The colonies are not very dense, with scatered zooids. Normally the end parts of the ectocist in each zooid, at the polypide level, presented a thickening like a collar. The most important characteristic of the polypide is the circular lophophore (fig. 1), with 19 tentacles, more or less equals in length (around $690 \mu \mathrm{m}$ ) and diameter (18 to $21 \mathrm{pm}$ ), with an intertentacular membrane in the lower parts of the tentacles.

We have not found statoblasts (sessoblasts) of this species in our samples of Abril and May 1989. Olivella (op. cit.) find two in samples taken on December but none in the succesive months. The sessoblasts (lacking peripheral float cells) were typically reniform.
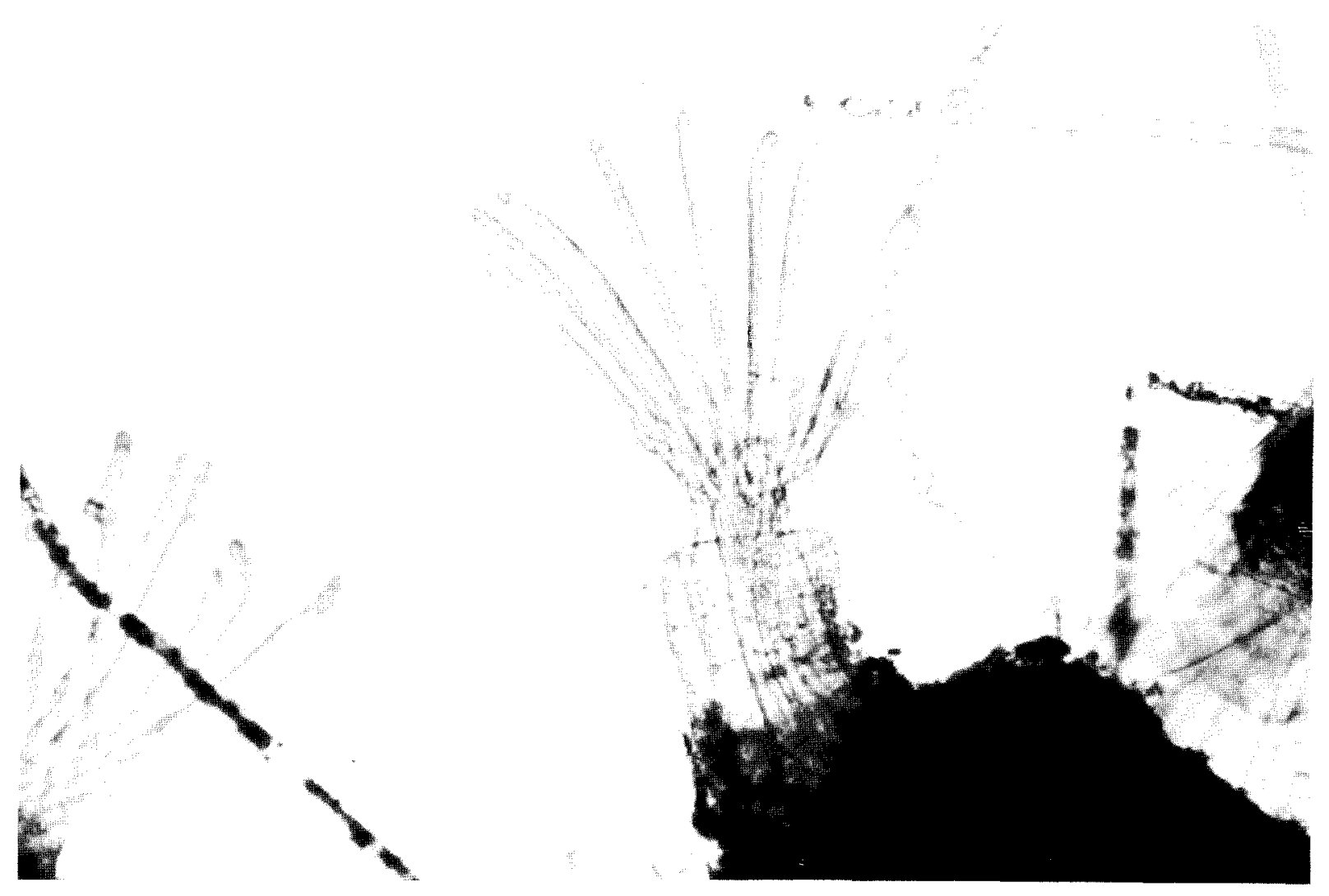

Figure 1.- Polypide of a Fredericella sultana colony with the characteristic circular lophophore open. Polipidio de una colonia de Fredericella sultana con el característico lofóforo circular abierto. 
Family Lophopodidae Rogick, 1935

Lophopus crystallinus (Pallas, 1768)

This is an uncommon or rare species. In North America it is known from the Schuylkill and Illinois rivers and Lake Erie (LACOURT, 1968) and it has been recorded from scattered lentic and lotic habitats in Central Europe, Great Britain, Ireland, southwestern Russia and Iran (Bushnell, 1974). There have been no reports of this species in recent years, probably due to a regresion of L. crystallinus in response to pollution (BUSHNELL, op. cit.) or to the difficulty in distinguishing colonies —often small, scarce and easily mistaken with snail egg masses. The usual substrate is an aquatic plant.

Lophopus crystallinus form globular, gelatinous, unsclerotized, hyaline colonies. They are usually small, around $1 \mathrm{~cm}$, but can reach up to $50 \mathrm{~cm}$. The polypides generally have 50 to 70 tentacles.

In Banyoles lake we have not found any kind of colonies of L. crystallinus, only statoblasts (floatoblasts) lying in the sediment. The floatoblasts are lemon-shaped in outline, from a frontal view; both extremities are pointed but have no spine (fig. 2a-c). They have brown color, darker in the capsular zone than in the annulus. The floatoblasts of this species are relatively large (table 1).

By SEM, we can observe an external layer with a characteristic irregular aspect on both the capsule and the annulus, although in the annulus the grain size is smaller (fig. 2k-1). This external structure coincides with the intrincate scale-like architecture described by ODA \& MUKAI (1985), and corresponds to the basophilic layer, originated by a gelatinous substance more or less sclerotized or
Table 1.- Size measurements (in $\mu \mathrm{m}$ ) of floatoblasts of Lophopus crystallinus and Plumatella repens. $\mathrm{n}=$ number of specimens measured.

Dimensiones (en pm) de los estatoblastos de L. crystallinus y P. repens. $\mathrm{n}=$ número de ejemplares medidos.

\begin{tabular}{lcc}
\hline & $\begin{array}{c}\text { Floatoblasts of } \\
\text { Lophopus } \\
\text { crystallinus } \\
(n=8)\end{array}$ & $\begin{array}{c}\text { Floatoblasts of } \\
\text { Plumatella } \\
\text { repens } \\
(n=24)\end{array}$ \\
\hline Maximum length & 1102 & 525 \\
Minimum length & 906 & 340 \\
Average length & 1017 & 453 \\
Maximum width & 659 & 381 \\
Minimum width & 597 & 216 \\
Average width & 626 & 320 \\
Average length/average width & 1,62 & 1,41 \\
\hline
\end{tabular}

corneous. In the annular portions, it is possible to see underlying hexagonal reticulations under the superficial structure (fig. 2g-h). Under this first layer there exists a second, chitinous and directly on and enclosing the flotation cells of the annulus, which we could not see in our material. Where the chitinous layer and the basophilic layer had released, it is possible to observe in the annulus a clear hexagonal reticulation formed by the thick walls of the columnar float cells (fig. 2i), which doubtless correspond to the underlying reticulations mentioned above. In general, our observations are in agreement with OdA \& MUKaI (op. cit.), but we should make the following observations. These authors state that in Lophopus crystallinus the underlying reticulations cannot be observed due to the superficial structure of the external layer, although they specify that the

Figure 2.- Lophopus crystallinus floatoblasts. a-c, General views. d, Atypical floatoblast. e, Lateral view. f, Floatoblast showing the two valves unwupled. g, Valve with the columnar floating cell layer of the annulus showing the poligonal reticulations. h, Detail of hexagonal reticulation in the annulus where it is possible to see the fine layer covenng the floating cells. i, Eroded annular extremity showing the characteristic empty columnar cell layer. j, Detail of annular flotation cells showing intercommunication holes. k-1, Surface structure, at the same magnification, and faint underlying reticulations in the annulus (k) and the capsule (I). Scales in $\mu \mathrm{m}$. In the former faint underlying reticulation are shown.

Flotoblastos de Lophopus crystallinus. a-c, Aspecto general. d, Flotoblasto de forma atípica. e, Flotoblasto mostrando las dos valvas desacopladas. f, Visión lateral. g, Detalle del retículo hexagonal del anillo, donde se observa la fina capa que cubre las células flotadoras. h, Valva en la que se aprecia el retículo poligonal que forman las paredes de la capa de células columnares del anillo de flotación. i, Extremo del anillo con las capas externas erosionadas mostrando las características células vacías de flotación. j, Detalle de las células de flotación del anillo donde se aprecia la existencia de poros de intercomunicación. k, 1, Estructura superficial, a la misma escala, del anillo y de la cápsula respectivamente. En el primero se intuye el retículo subyacente (underlying reticulations). Escalas en pm. 
statoblast used in their study might have been immature, as it was taken out from a fixed colony. In our case, we used released and presumably mature statoblasts, and we can confirm that the basophilic layer remains in situ after release from the colony and that the underlying reticulations are also conspicuous (fig. 2k). We also observed clearly the presence of intercommunication porus between cells in the annulus (fig. $2 \mathrm{j}$ ). Finally, we found some specimens without the characteristic
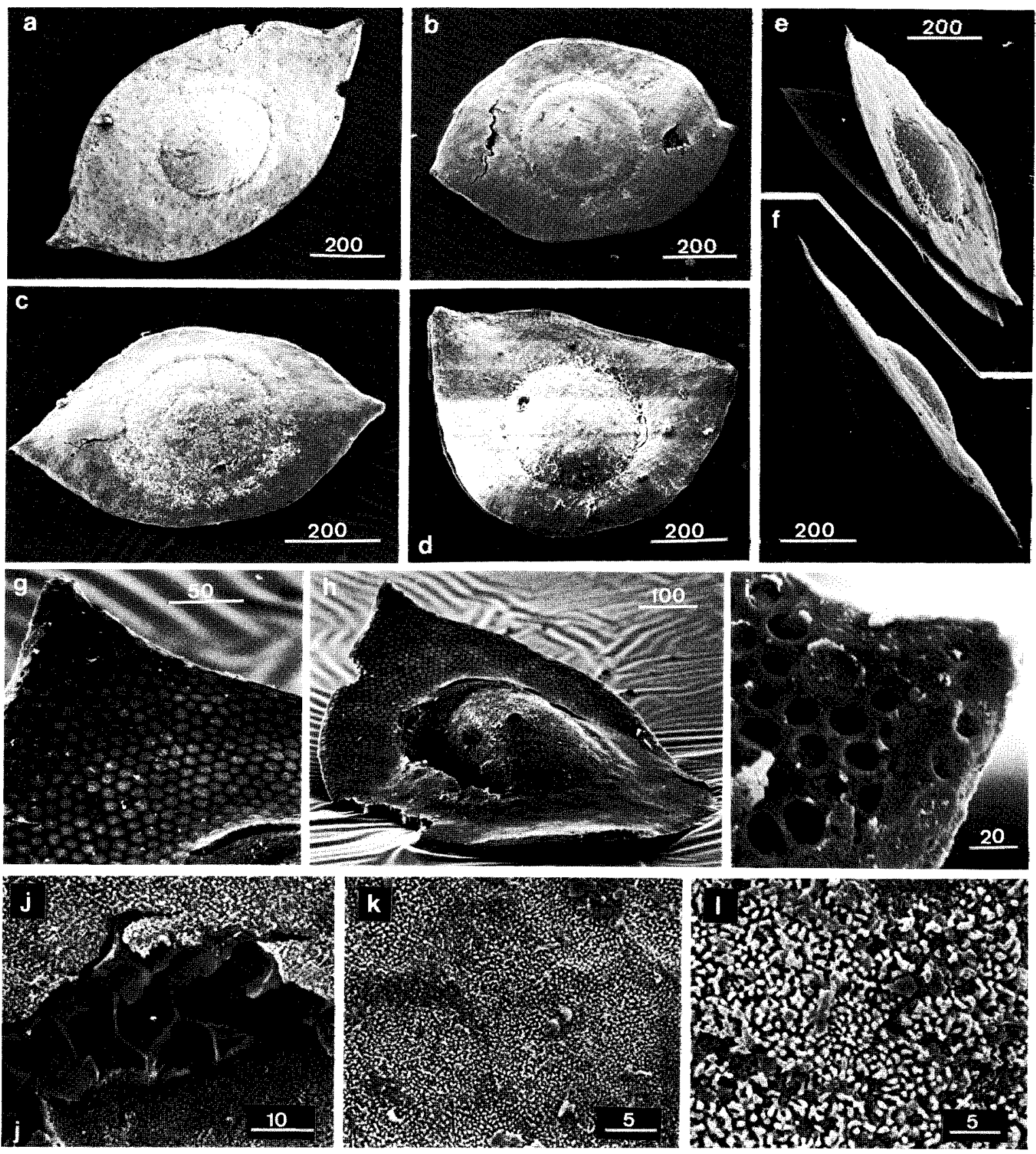

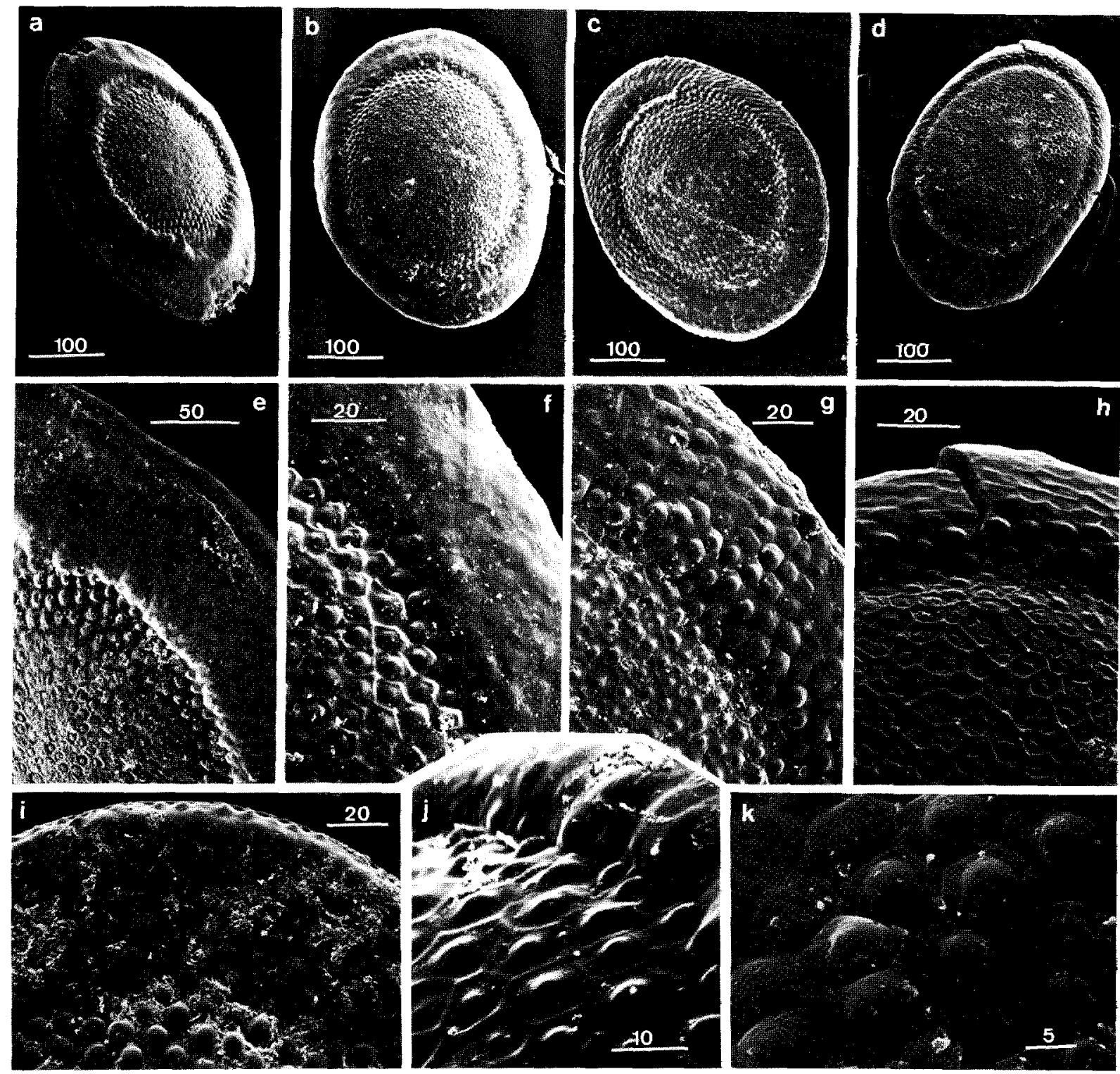

Figure 3.- Plumatella repens floatoblasts. a-d, General views of differents floatoblasts. e-h, Details of the annulus and the capsule showing the great vanability of the superficial structures. Each one of the photos correspond to the above floatoblast. i, Id. e-h. j, Detail at great magnification of the contact zone between the capsule and the annulus and the poligonal capsular structure with raised walls and papilles. $k$, Annular portion with poligonal structure with papilles but without raised walls. Scales in $\mu \mathrm{m}$.

Flotoblastos de Plumatella repens. a-d, Aspecto general de varios flotoblastos. e-h, Detalles del anillo y la cápsula mostrando la gran variabilidad de las estructuras superficiales. Cada foto se corresponde respectivamente con las fotos generales a-d. i, id. e-h. j, Detalle a mayor aumento de la zona de contacto entre la cápsula y el anillo, y de la estructura poligonal carenada con papilas centrales de la cápsula. $\mathrm{k}$, Estructura poligonal del anillo presente en algunos de los ejemplares estudiados, con papilas pero sin paredes carenadas. Escalas en ym. 
lemon shape, but with clear L. crystallinus characters in the capsule and the annulus, so this atypic morpho may be only simple intraspecific variability (fig. 2d).

Family Plumatellidae Allman, 1856

Plumatella repens (Linné, 1758)

Plumatella is the largest genus of this group, with 12 species, and the most complicated from the taxonomical point of view, so the definition of species depends on the author's criterion (MARGALEF, 1983). That is the reason for large studies of this species using the scanning electron microscope and electrophoretical technics (MUNDY, 1980; Mundy \& Thorpe, 1979,1980; Thorpe \& Mundy, 1980).

Plumatella repens is a cosmopolitan species, also present at high latitudes (LACOURT, 1968; BusHNELL, 1973). In Europe it is the most common species (GeIMER \& Massard, 1986). In the Iberian peninsula it has been recorded in the Pyrenees (MARGalef, 1948, 1952) and is considered common by this author (MARGALEF, 1955). Recently, Busouets (1988) recorded abundant $P$. repens (?) with colonies similar to that of $P$. fungosa in 6 artificial ponds (Graugés and Serret ponds, in Bergueda area, Catalonia).

This is a eurioc species, common in lakes, streams, ponds, and even marshes. It is found on all kinds of substrate: aquatic plants, stones, bottles, etc. $P$. repens seems to tolerate lower temperatures and oligotrophic conditions better than the related similar species P. fungosa, but both can live together and furthermore both colonies can interbreed each other. This is one of the reasons for the difficulties in identifying these two species (Geimer \& Massard, 1986).

So far we have observed no colonies of P. repens on the littoral of Banyoles lake. The statoblasts studied had the typical oval or elliptical outline form, even though some specimens can be ovoid (with the capsule in an excentric position) or rhomboid or navicular-shaped (fig. 3a-d). They are dark brown, sometimes a little redish or ochre. Length measurements are summarized in table 1.

The dorsal part of the capsule is less covered by the annular float cells than the ventral part. Under the optical microscope we cannot observe any kind of superficial structure in the annulus, but in the capsule the reticulations are clear. These reticulations correspond a polygonal, mostly hexagonal, structure with raised walls and central papilles (fig. 3j). This structure is present both in the dorsal and ventral parts of the capsule.

When observed by the scanning electron microscope, structural details can be seen. In the capsule the reticulations can disappear near the borders. The surface of the annulus is usually without defined structures (fig. 3e-f), but in some cases there are tubercules or papilles (fig. 3i), and we have even observed specimens with all the annular surface covered by polygonal and no ridged reticulations (fig. $3 \mathrm{~g}$ and $\mathrm{k}$ ). Nevertheless, once we founded a lightly ridged reticle in the annulus, but not so apparent as in the capsule and without the internal papilles (fig. $3 \mathrm{~h}$ ). In the suture zone between the two valves is a flange which has tubercles on each side of it, normally arranged alternately along the flange (fig. 3a and e). Using the Geimer \& Massard (1986) criteria the floatoblasts seem to be of $P$. repens, despite the similarity with $P$. fungosa, although it is clear that there is great variability in the characters noted by these authors when used as the basis for taxonomic descriptions of our specimens.

When the two valves are uncoupled it is possible to observe the internal layer of the capsule in direct contact with the germinative cells (fig. 4c). Their surface presents a dendroid structure, and has a thin border, around $6 \mu \mathrm{m}$ (fig. $4 \mathrm{~d}-\mathrm{e}$ ). Annular floating cells are intercommunicated by holes, bordered by little spines (fig. 4a-b).

\section{DISCUSSION}

Even though the material studied is not extensive or complete, we have no doubt about the presence of at least three bryozoans species in $\mathrm{Ba}-$ nyoles lake, corresponding to three diferent genus. Great difficulties appear in identifying species of Plumatella genus. On the observations by the SEM and in agreement with GeIMER \& MASSARD (1986) criteria we conclude that our statoblasts specimens might be of $P$. repens, for the following reasons: 1) lack, in general, of ridged reticulations in the annulus, and a nearly smooth surface, with some tubercules in the most internal part of the annulus in contact with the capsule; 2 ) suture line 
with alternating tubercles. All these characters show great variability in our samples, greater than that assumed by the abovenamed authors. Hence, further studies on colonies of this species in $\mathrm{Ba}$ nyoles lake are needed.

There seems to exist an association tendency of F. sultana with Paludicella articulata and a clear exclusion between $P$. repens and $P$. emarginata, but by no means between $\mathrm{P}$. repens and P. fungosa (Geimer \& Massard, 1986). No data has been published about specific association of F. sultana with $\mathrm{P}$. repens. At the moment, $\mathrm{P}$. articulata and $\mathrm{P}$. fungosa have not been recorded in Banyoles lake, although we cannot exclude this poss-
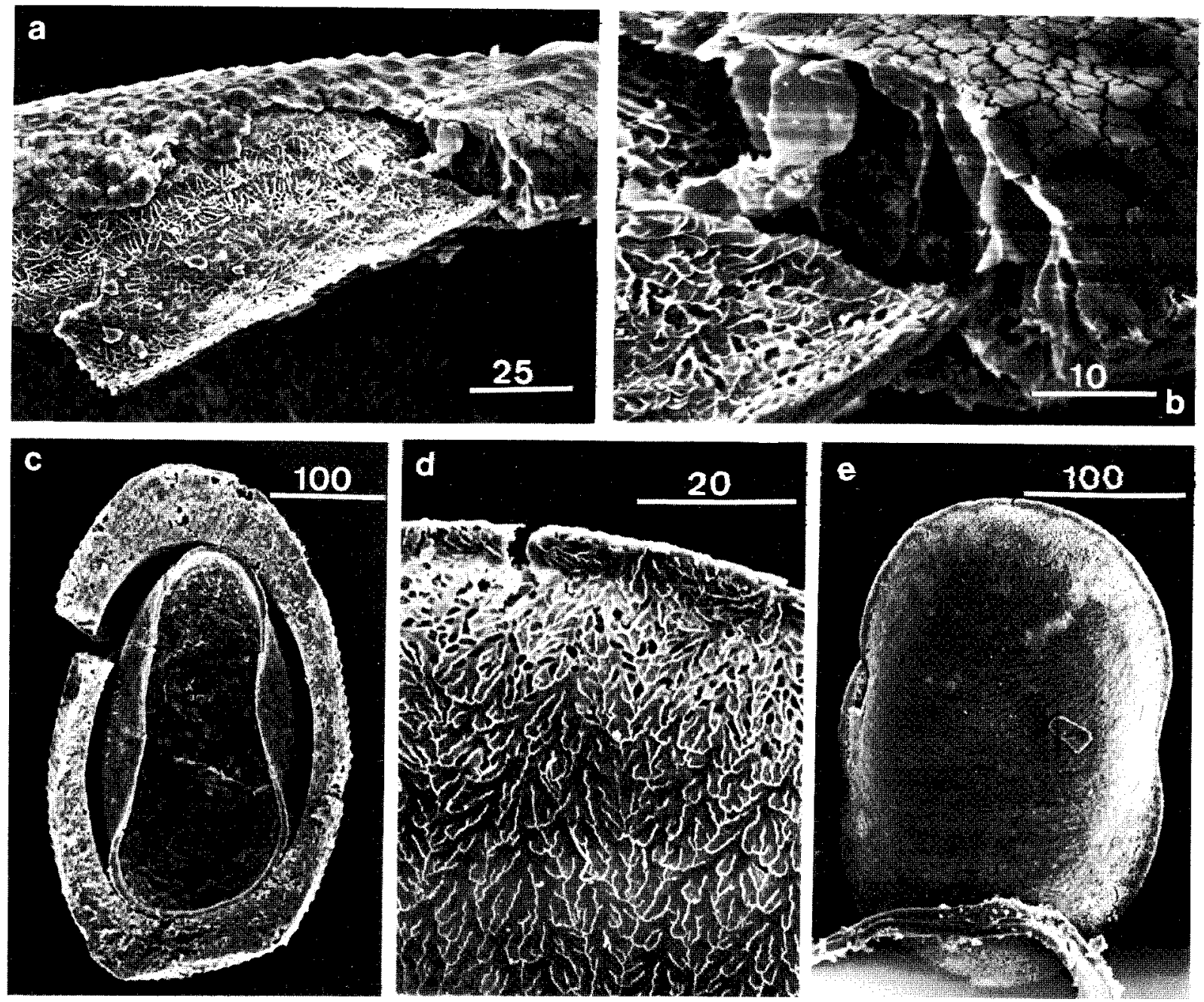

Figure 4.- a, Plumatella repens eroded floatoblasts showing the internal layer of the capsule and the structure of the annulus. b, Detail of columnar cells in the annulus with intercommunication holes bordered by small spines. c. Internal view of a floatoblast valve in which it is possible to observe the most internal layer in contact with the germinative cells. $d$. Detail of the dendroid superficial structure of these internal layer. E, Internal capsular layer released from the valve. Scales in $\mu$.

a, Flotoblasto de $\boldsymbol{P}$. repens erosionado mostrando la capa interna de la cápsula y la estructura del anillo. b. Detalle de las células columnares del anillo y de los poros de intercomunicación, los cuales aparecen bordeados por pequeñas espinas. c, Aspecto interno de una valva de flotoblasto donde puede observarse la capa más interna que se halla en contacto con las células germinativas. d, Detalle de la estructura dendroide superficial de esa capa interna. e, Capa interna aislada de la valva. Escalas en $\mu \mathrm{m}$. 
ibility. The same authors recorded F. sultana and $P$. repens together with other species ( $P$. fungosa, P. fruticosa, Paludicella articulata, Cristatella mucedo and Hyalinella punctata), in several lakes in central Europe.

In general, freshwater bryozoans prefer unpolluted waters. However, some species, like P. repens and F. sultan -an tolerate highly eutrophicated and polluted conditions (BUSHNELL, 1974); while L. crystallinus seem to be an intolerant species. We have not found at the moment any colonies of Lophopus crystallinus, which may be due to a lack of research in this lake or to response to eutrophication process in Banyoles lake. In this case, statoblasts collected in the sediment might be a subfossil reminiscence of the presence of this species, in regression all over the world (BusHNELL, 1974).

Not much information about the trophic conditions of Banyoles lake can be revealed by the record of these three species, as F. sultana and $\mathrm{P}$. repens are the most ubiquitous freshwater bryozoan species, and can live in many different envi- ronmental conditions. But the data do not contradict the mesotrophy detected by the macroinvertebrate benthic communities (RIERADEVALL \& PRAT, in press).

Finally, the presence of only 4 species of freshwater bryozoans in Spain as compared to the 14 species recorded in Europe suggests that more studies on this topic are needed.

\section{ACKNOWLEDGEMENTS}

We wish to express our appreciation to Dr. M. Durfort for facilities in using the photomicroscope equipment of the Cytology Unit. We are also thankful to Dr. M. Zabala for his comments on the topic and to Dr. N. Prat for the revision of the manuscript. Observations and photographies by scanning electron microscope were made in the Electron Microscope Service of Barcelona University.

\section{RESUMEN}

\section{BRIOZOOS DEL LAGO DE BANYOLES (NE ESPAÑA)}

Se presenta el hallazgo de tres especies de briozoos de agua dulce (Ectoprocta Phylactolaemata) en el lago de Banyoles: Fredericella sultana, Lophopus crystallinus y Plumatella repens; la cita de las dos primeras es nueva para España. Asimismo se presentan detalles de la estructura de los flotoblastos de L. crystallinus y P. repens, observada al microscopio electrónico de barrido.

\section{BiRLIOGRAPHY}

AltaBA, C.R., 1985. Els bivalves d'aigua dolça recents dels Països Catalans. Tesi de Llicenciatura. Universitat de Barcelona. $237 \mathrm{pp}$.

BushNELL, J.H., 1973. The freshwater Ectoprocta: a zoogeographical discussion. In: G.P. LARwood (ed), Living and fossil Bryozoa. Recent advances in research, pp.: 503-521. Academic Press, London.

BuSHNELL, J.H., 1974. Bryozoans (Ectoprocta). In: C. W. HART \& S.L.R. FULLER (eds): Pollution ecology of freshwater invertebrates, pp.: 157-194. Academic Press. London.

BusQuets, J.M., 1988. La vida microscopica de les aigües de Graugés. Els Briozous. In: Col-lectiu Berguedà de Ciències
Naturals, La vida als estanys de Graugés, pp.: 134-141. Els Llibres de l'Àmbit, 2. Edicions de l'Albí, Berga.

Casadevall, M., A. Vila \& R. Moreno-Amich, 1985. Aproximació a la fauna malacològica de I'estany de Banyoles mitjançant l'anàlisi de les restes retingudes pel sediment. Scientia Gerund. 11: 73-80.

Geimer, G. \& La Massard, 1986. Les Bryozoaires du GrandDuché de Luxembourg et des Régions limitrophes. Trav. Scient. Musée Hist. Nat. Luxembourg 7: 184 pp.

Guerrero, R., C. Abella \& M.R. Miracle, 1978. Spatial and temporal distribution of bacteria in a meromictic karstic lake basin: relationships with physicochemical parameters and zooplancton. Verh. Internat. ver. Limnol. 20 : 2264-2271. 
HaAs, F., 1916. Die Najaden des Sees von Bañolas und ihre theoretische Bedeutung. Treb. Inst. Cat. Hist. Nat. 2: 9-31.

LACOURT, A.W., 1968. A monograph of the freshwater Bryozoa. Phylactolaemata. Zool. Verh. Leiden 93: 1-159.

MARGALEF, R., 1946. Materiales para el estudio de la biología del lago de Bañolas (Gerona). Publicaciones del Instituto de Biología Aplicada 1: 27-78.

MARGALEF, R., 1948. Flora, fauna y comunidades bióticas de las aguas dulces del Pirineo de la Cerdana. Monogr. Inst. Est. Pirenaicos 11: 1-226.

Margalef, R., 1952. La vida en las aguas dulces de Andorra ler. Congr. Int. del Pirineo. Inst. Est. Pirenaicos, 69: 1-107.

Margalef, R., 1955. Los organismos indicadores en la limnología. Minist. Agricultura, Dir. Gral. Montes, Caza y Pesca. 300 pp.

Margalef, R., 1983. Limnología. Ed. Omega. Barcelona. $1010 \mathrm{pp}$.

Miracle, R., 1976. Distribución en el espacio y el tiempo de las especies de zooplancton del lago de Banyoles. Monografias 5. ICONA. $270 \mathrm{pp}$

MundY, S.P., 1980. A key to the British and European Freshwater Bryozoans. Freshwater Biological Association. Scientific Publications 41: $32 \mathrm{pp}$.
Mundy, S.P. \& J.P. THORPE, 1979. Biochemical genetics and taxonomy in Plumatella fungosa and P. repens (Bryozoa: Phylactolaemata). Freshwat. Biol. 9: 157-164

MunDY, S.P. \& J.P. Thorpe, 1980. Biochemical genetics and taxonomy in Plumatella coralloides and $P$. fungosa and a key to the British and European Plumatellidae (Bryozoa: Phylactolaemata). Freshwat. Biol. 10: 519-526.

ODA, S. \& H. MuKaI, 1985. Fine surface structure of the statoblasts of higher Phylactolaemata Bryozoans. In: C. NiELSEN \& G.P. LARWOOD (eds.), Bryozoa: ordovician to recent, pp.: 234-244. Olsen \& Olsen Fredensborg.

Olivella, I., 1974. Estudio de esponjas y briozoos del lago de Banyoles (unpubl. paper).

Planas, D., 1973. Composición, ciclo y productividad del fi. toplancton del lago de Banyoles. Oecologia aquatica 1: 3-106.

RieradeVAll, M. \& N. PRAT, in press. Benthic fauna of Banyoles lake. Verh. Internat. ver. Limnol.

THORPE, J.P. \& S.P. Mundy, 1980. Biochemical genetics and taxonomy in Plumatella emarginata and $P$. repens (Bryozoa: Phylactolaemata). Freshwater Biol. 10: 361-366.

Traveset, A., 1985. Contribució al coneixement de les esponges d'aigua dolça de la península Ibèrica. Tesi de Llicenciatura. Universitat de Barcelona. 